\title{
Involvement of CD44 in leukocyte recruitment to the rat testis in experimental autoimmune orchitis
}

\author{
V A Guazzone, B Denduchis and L Lustig \\ Centro de Investigaciones en Reproducción, Facultad de Medicina, Universidad de Buenos Aires, \\ Paraguay 2155 piso 10, C1121 ABG, Buenos Aires, Argentina \\ Correspondence should be addressed to VA Guazzone; Email: ciruba@fmed.uba.ar
}

\begin{abstract}
Experimental autoimmune orchitis (EAO) is characterized by an interstitial mononuclear cell infiltrate and a severe lesion of the seminiferous tubules with germ cells that undergo apoptosis and sloughing. The aim of this study was to determine the role of CD44 in testicular leukocyte recruitment in EAO. The biological functions of CD44 have been attributed to the generation of a functionally active hyaluronan-binding phenotype. Orchitis was induced in Sprague-Dawley adult rats by active immunization with an emulsion of testicular homogenate and complete Freund's adjuvant using Bordetella pertussis as co-adjuvant. Control rats $(C)$ injected with saline and adjuvants and normal $(N)$ untreated rats were also studied. $C D 44$ expression was analyzed by flow cytometry in peripheral blood mononuclear cells (PBMC) and lymph node cells isolated from rats at different times after the first immunization. We observed an increase in the mean fluorescence intensity of both samples in the $C$ and experimental (E) groups only after the immunization period. A significant decrease in percentage of CD44 + PBMC and in mean fluorescence intensity was observed in rats with orchitis compared with the $C$ group. By in vitro hyaluronic acid-binding assay we demonstrated that the percentage of PBMC adhesion was higher in the E group compared with the $C$ and $N$ groups. By immunohistochemistry, we observed a significant increase in the number of CD44 + cells in the testicular interstitium of rats with severe orchitis compared with the $\mathrm{N}$ and $\mathrm{C}$ groups. These results suggested that the CD44 molecule is involved in the homing of lymphomonocytes into the testes of rats with autoimmune orchitis.

Reproduction (2005) 129 603-609
\end{abstract}

\section{Introduction}

Acute or chronic inflammation of the male genital tract may result in alterations of spermatogenesis, steroidogenesis and fertility (Hales et al. 1999). Orchitis in men usually occurs as a consequence of different injuries induced by trauma or physical or infectious agents. The interaction of immune cells with spermatic antigens is one of the pathogenic mechanisms involved in testis autoimmunity. Different models of experimental autoimmune orchitis (EAO) have been useful in understanding testicular cell interactions. EAO has been induced in different species by active immunization with spermatic antigens, by adoptive $\mathrm{T}$ cell transfer or by neonatal thymectomy (Itoh et al. 1992, Tung et al. 1994).

We previously described an experimental model of EAO in rats (Doncel et al. 1989) characterized by an increased number of immune cells in the testicular interstitium and different degrees of germ cell apoptosis and sloughing in the seminiferous tubules (Lustig et al. 1993, Suescun et al. 2003, Theas et al. 2003). We also showed that monocyte chemoattractant protein-1 (MCP-1) is highly expressed in testicular interstitial cells, suggesting that this chemokine has an important role in recruiting immune cells to the testis in rats undergoing autoimmune orchitis (Guazzone et al. 2003). Although it is well known that a cascade of adhesion receptors including integrins, selectins and members of the Ig superfamily are involved in leukocyte cell trafficking, this work focuses on the study of the CD44 adhesion molecule in EAO, since it has been suggested (Estess et al. 1998) that circulating lymphocytes bearing activated CD44 might be markers for autoimmune and chronic inflammatory diseases.

The CD44 molecule is involved in cell-cell and cellmatrix interactions. It comprises a family of $85-200 \mathrm{kDa}$ transmembrane glycoproteins widely expressed in a variety of cell types (Gee et al. 2004). CD44 functions as a hyaluronic acid (HA) receptor and, although most blood cells express CD44, few of them recognize HA (Lesley et al. 1993). The acquisition of HA-binding ability by the CD44 molecule could be explained by structural variations in its extracellular domain, oligomerization of CD44 on the cell membrane, phosphorylation of its 
cytoplasmic tail and alterations in the $\mathrm{N}$ - and O-linked glycosylation pattern (Gee et al. 2003). Further, it has been reported that lipopolysaccharide (LPS) and tumor necrosis factor- $\alpha$ (TNF $\alpha$ ) up-regulate CD44-mediated HA binding in LPS-stimulated monocytes (Levesque \& Haynes 1996, 1997). Activated lymphocytes bind HA present on the endothelium and this specific binding facilitates the rolling and extravasation of leukocytes into the inflammation site. In addition, a recent work by Nandi et al. (2004) demonstrated that selective and co-operative interaction between CD44 and very late antigen- $4\left(\alpha_{4} \beta_{1}\right.$ integrin) is required for $T$ cell extravasation.

In this study we focused our attention on the expression of CD44 in the lymphomononuclear cells of lymph nodes, peripheral blood and the testicular interstitium of rats undergoing autoimmune orchitis in order to determine the involvement of this molecule in leukocyte traffic to the testis.

\section{Materials and Methods}

\section{Animals}

Male Sprague-Dawley rats aged 50-60 days were kept at $22{ }^{\circ} \mathrm{C}$ with a $14 \mathrm{~h}$ light:10 h darkness schedule and fed with standard food pellets and water ad libitum. The animals were killed according to protocols for animal use, following the $\mathrm{NIH}$ guidelines for the care and use of experimental animals.

\section{Immunization schedule}

Rats in the experimental (E) group were immunized with testicular homogenate (TH) prepared as previously described (Doncel et al. 1989). Briefly, rat testes were decapsulated, diluted in an equal volume of saline and disrupted in an Omni mixer for $30 \mathrm{~s}$. The final concentration was $500 \mathrm{mg} / \mathrm{ml}$ wet weight. The E group rats were injected three times with $200 \mathrm{mg}$ wet weight of $\mathrm{TH} /$ dose per rat, at 0,15 and 30 days. Antigen $(0.4 \mathrm{ml})$ emulsified with $0.4 \mathrm{ml}$ complete Freund's adjuvant (CFA) was injected intradermally in footpads and at multiple sites near ganglionar regions. The first two immunizations were followed by an i.v. injection of $0.5 \mathrm{ml}$ Bordetella pertussis (Bp) (strain 10536; Instituto Malbrán, Buenos Aires, Argentina) containing $10^{10}$ micro-organisms and the third one by an i.p. injection of $10^{9}$ micro-organisms. The control (C) group rats were injected with an emulsion of saline and CFA, and $\mathrm{Bp}$ was used in the same conditions as the $\mathrm{E}$ group. $\mathrm{E}$, $\mathrm{C}$ and normal untreated rats $(\mathrm{N})$ were killed on different days $(7,30,50$ and 100) after the first immunization. Blood was collected and sera stored at $-70^{\circ} \mathrm{C}$ until use. Testes were removed, fixed in Bouin's solution and embedded in paraffin or quickly frozen for cryostat sections. Popliteal lymph nodes were removed for lymphocyte isolation.

\section{Histopathology}

The histopathology of the testis was studied in sections obtained from three different levels and stained with hematoxylin-eosin.

\section{Isolation of leukocytes}

Popliteal lymph nodes and peripheral blood were obtained from N, C and E rats. Lymph nodes were cut with scissors into small pieces in phosphate-buffered saline (PBS; $0.1 \mathrm{M}, \mathrm{pH} 7.2$ ) with $0.03 \%$ azide plus $10 \%$ fetal bovine serum (FBS) and sieved through a stainless steel mesh. The cell suspension was quickly passed through a syringe with nylon wool at room temperature in order to deplete the suspension of dead cells and fat tissue. Peripheral blood mononuclear cells (PBMC) were purified by Ficoll-Hypaque gradient centrifugation. Cells from both samples were then centrifuged and counted in an hemocytometer and viability was assessed by trypan blue exclusion.

\section{Flow cytometric analysis}

CD44 expression was analyzed by flow cytometry in PBMC and lymph node cells (LNC). Cells $\left(2 \times 10^{6}\right)$ from both samples were incubated with primary monoclonal antibody mouse anti-rat CD44 ( $\operatorname{lgG}_{2 \mathrm{~A}_{\kappa}}$ PharMingen, San Diego, CA, USA) for $30 \mathrm{~min}$. After washing in cold PBS with $10 \%$ FBS (PBS/FBS), cells were incubated with antimouse fluorescein isothiocyanate-conjugated IgG (1:50) (Vector Laboratories, Burlingame, CA, USA) for $30 \mathrm{~min}$. Cells were then washed twice with PBS/FBS. The whole procedure was carried out at $4{ }^{\circ} \mathrm{C}$. Labeled cells were measured by flow cytometry using an Ortho Diagnostic Systems Cytoron Absolute (Johnson \& Johnson, Raritan, NJ, USA). A propidium iodide exclusion gate was pre-set to ensure that only viable cells were acquired. Analysis was done on the total lymphomonocyte fraction. In all experiments, background threshold levels were set using irrelevant mouse immunoglobulins $\left(\operatorname{lgG}_{2 A_{\kappa}}\right)$ and an antirat lymphocyte W3/13 (Accurate Chemical Science Co., Westbury, NY, USA). These controls allowed us to establish the optimal cut-off for each population analyzed.

\section{In vitro binding of PBMC and LNC to HA}

A flat-bottom 96-well microplate (Maxisorp, Nunc, Roskilde, Denmark) was coated with $1 \mathrm{mg} / \mathrm{ml}$ per well HA (rooster comb; Sigma Chemical Co., St Louis, MO, USA) in PBS. After $16 \mathrm{~h}$ of incubation at $4{ }^{\circ} \mathrm{C}$, the microplate was washed twice with PBS and $2.5 \times 10^{5}$ cells were added to each coated well. Bound cells were washed after $1 \mathrm{~h}$ of incubation $\left(5 \% \mathrm{CO}_{2}, 37^{\circ} \mathrm{C}\right)$ and were stained using the CellTiter 96 Aqueous Non-Radioactive Cell Proliferation Assay (Promega, Madison, WI, USA). Absorbances $(490 \mathrm{~nm})$ were read in an ELISA microplate reader (BioRad, Hercules, CA, USA). In another experiment, bovine 
testis hyaluronidase (Sigma Chemical Co.), at a concentration of $900 \mathrm{U} / \mathrm{ml}(90 \mathrm{U} /$ well), was added to the HAcoated microplates. After $30 \mathrm{~min}$ of incubation $\left(5 \% \mathrm{CO}_{2}\right.$, $37^{\circ} \mathrm{C}$ ), microplates were washed and $2.5 \times 10^{5}$ cells were added to each well. We also studied cell binding to uncoated wells. Percentage of adhesion was calculated by the following equation: (bound absorbance per well divided by maximal $2.5 \times 10^{5}$ cells absorbance) $\times 100$.

\section{Immunohistochemical techniques}

Testis cryostat sections $(6 \mu \mathrm{m}$ thick) were fixed in cold acetone. An immunoperoxidase technique using the avidin-biotin system (ABC Vectastain Kit; Vector Laboratories) was applied. Sections were washed in PBS and blocked with normal horse serum. After $40 \mathrm{~min}$ of incubation with the primary monoclonal antibody mouse anti-rat CD44 $(2.5 \mu \mathrm{g} / \mathrm{ml})$ (PharMingen) sections were incubated with biotinylated horse anti-mouse Ig (Vector Laboratories). Endogenous peroxidase activity was blocked with $0.3 \% \quad \mathrm{H}_{2} \mathrm{O}_{2}$ in methanol for $30 \mathrm{~min}$. The reaction was then amplified using the $A B C$ Vectastain kit and 3-3'diaminobenzidine- $\mathrm{H}_{2} \mathrm{O}_{2}$ (DAB Substrate Kit; Vector Laboratories) was used as peroxidase substrate. Sections were counterstained with hematoxylin. Negative controls were obtained by incubating sections with PBS or mouse IgG $(2.5 \mu \mathrm{g} / \mathrm{ml})$ (Vector Laboratories) instead of the primary antibody. CD44 + cells were counted using a $25 \times$ objective. The total number of fields counted for each section was 40, and three animals/group per day after the first immunization were studied. The number of CD44 + cells per unit volume testis was calculated as previously described (Suescun et al. 2003) using the Floderus equation (Floderus 1944).

\section{Statistical data analysis}

For statistical evaluations, the non-parametric MannWhitney rank test was used. A value of $P \leq 0.05$ was considered significant.

\section{Results}

\section{Histopathology}

Seventy five percent of rats from the $E$ group developed autoimmune orchitis. As previously described (Doncel et al. 1989), the testicular lesion was characterized by an interstitial mononuclear cell infiltrate composed mainly of macrophages and lymphocytes intermingled with Leydig cells and different degrees of germinal cell sloughing of the seminiferous tubules. Fifty days after first immunization few foci of seminiferous tubules with germ cell sloughing were observed. In rats with severe orchitis (100 days), large areas of aspermatogenic seminiferous tubules in which only spermatogonia and Sertoli cells attached to the tubular wall were observed. None of the rats from the $\mathrm{N}$ and $\mathrm{C}$ groups revealed pathological alterations of the testis.

On the basis of histopathologic observations, animals were grouped into 7-30 days (no testicular damage) corresponding to the immunization period, 50 days (focal orchitis) and 100 days (severe orchitis). Rats from the $E$ group that did not develop orchitis after 50 days were not studied.

\section{CD44 expression on PBMC and LNC}

We examined by flow cytometry the expression of CD44 molecules on the surface of PBMC and LNC isolated from $\mathrm{N}, \mathrm{C}$ and $\mathrm{E}$ rats on different days after the first immunization. CD44 molecules were found to be expressed on the surface of PBMC and LNC in every group studied. An increase in mean fluorescence intensity was observed in the $\mathrm{C}$ and $\mathrm{E}$ groups after the immunization period compared with rats killed at 7-30 days (Fig. $1 \mathrm{~b}$ and Fig. 2b). Analysis of PBMC showed a decreased number of lymphocytes expressing CD44 in the blood of rats with severe orchitis (Fig. 1a). The mean fluorescence intensity corresponding to this subpopulation also decreased compared with rats from the C group (Fig. 1b). In LNC, a similar profile to the one observed in PBMC was obtained although the difference in the percentage of CD44 + cells among the C and $\mathrm{E}$ groups was not significant (Fig. $2 \mathrm{a}$ and b).

\section{In vitro binding of PBMC and LNC to HA}

To investigate the function of the CD44 molecule expressed by PBMC and LNC, we analyzed it in cell attachment to HA. PBMC and LNC from rats with orchitis were capable of adhering to a plastic surface coated with a concentrated HA solution. To test the specificity of the cell binding to $\mathrm{HA}$, we added hyaluronidase to the in vitro assay. We also evaluated the cell binding to uncoated wells. As shown in Fig. 3, hyaluronidase blocked HA-mediated adhesion. Cells from the E group showed a higher attachment to HA compared with uncoated plastic wells (PBMC: $P=0.016$ and LNC: $P=0.029$ ). An increase in percentage of adhesion was observed in PBMC and LNC from the $\mathrm{E}$ rats compared with the $\mathrm{N}$ rats $(P=0.032$ and $P=0.019$ respectively) (Fig. 3). PBMC from the $E$ group also showed a higher percentage of adhesion compared with the $\mathrm{C}$ group (Fig. 3a). No difference in the percentage of LNC adhesion to HA was observed between the $\mathrm{E}$ and $\mathrm{C}$ groups (Fig. 3b).

\section{Immunohistochemical expression of CD44}

Positive CD44 lymphomononuclear cells were present in interstitial areas around or in the lumen of blood vessels; no labeled cells were observed inside the seminiferous tubules of testes from any of the rats studied (Fig. 4). No staining was observed in sections incubated with PBS or mouse IgG instead of the primary antibody. 
(a)

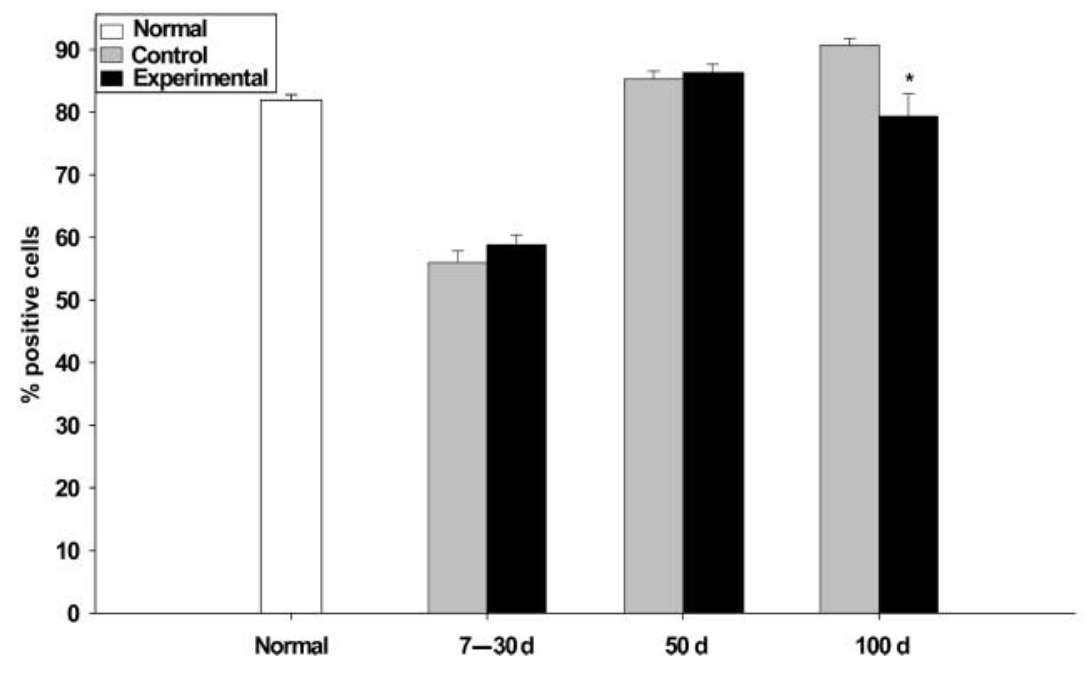

(b)
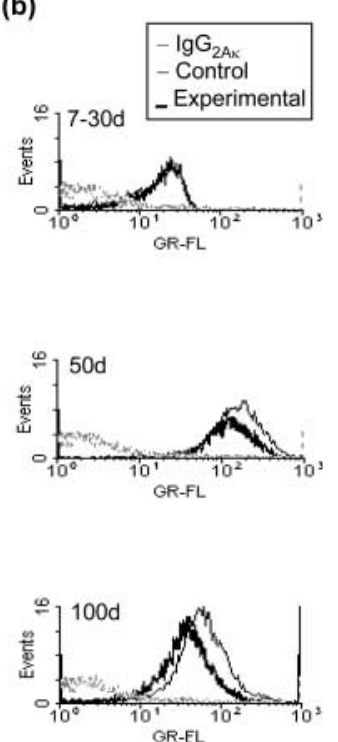

Figure 1 CD44 expression on PBMC. (a) Percentage of CD44 + cells. Values are means \pm S.E.M. of four rats/group per day after first immunization. $* P=0.0046$ vs $C$ (100 days). (b) Histogram overlays demonstrating the mean fluorescence intensity of CD44. E group (thicker lines), $C$ group (thinner lines) and background staining levels assessed using irrelevant mouse immunoglobulins ( $\operatorname{lgG}_{2 \mathrm{~A}_{\kappa}}$ ) (grey lines). The same negative background levels were observed in cells isolated from the $\mathrm{C}$ and $\mathrm{E}$ rats. $\mathrm{d}=$ days after first immunization. GR-FL $=$ Green Fluorescense.

As shown in Table 1, no significant differences in the number of labeled cells were observed among the $\mathrm{N}$ and $\mathrm{C}$ group. When comparing the $\mathrm{E}$ group with the $\mathrm{C}$ group significant differences in the number of CD44+ cells were only observed for rats with severe orchitis killed at 100 days. The increase in the number of CD44 + cells was associated with a higher degree of testicular damage.

(a)

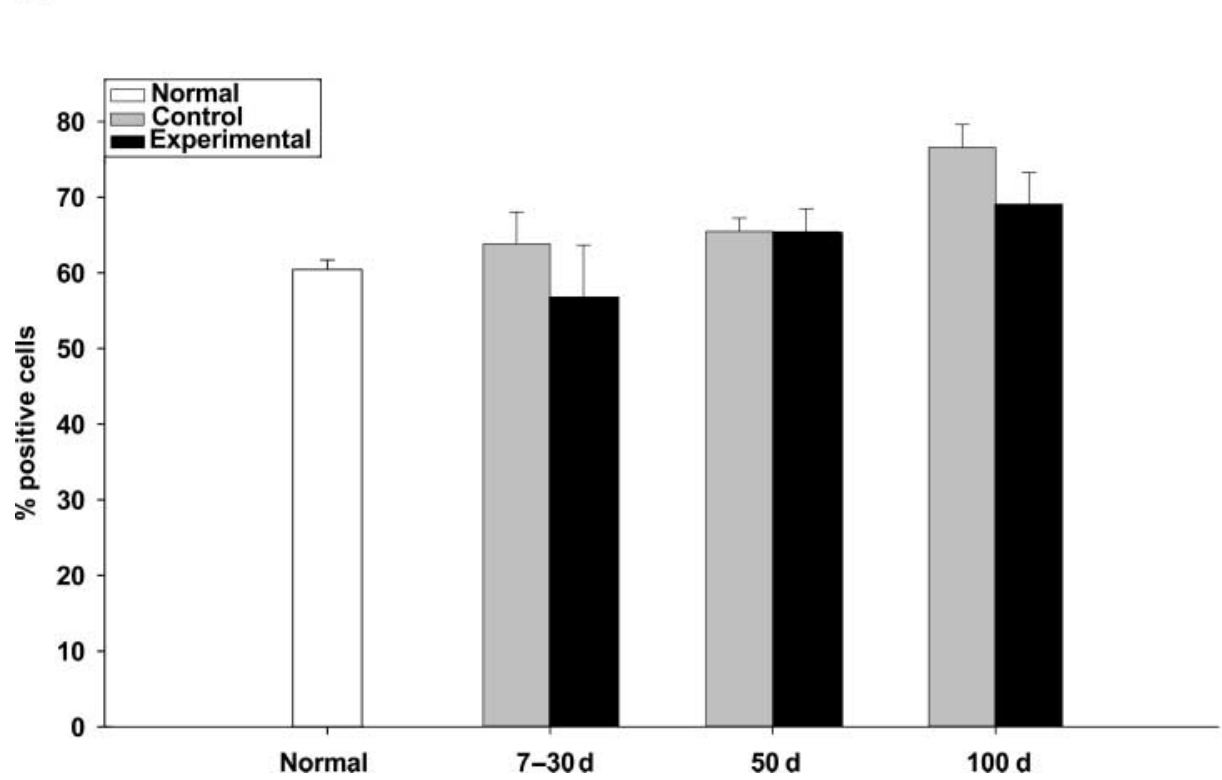

\section{Discussion}

We studied CD44 expression by lymphomononuclear cells from lymph nodes, peripheral blood and testes of rats undergoing an autoimmune orchitis. CD44 was found to be expressed on the surface of PBMC and LNC in the $\mathrm{E}, \mathrm{C}$ and $\mathrm{N}$ groups. It has been demonstrated that resting normal $\mathrm{T}$ and $\mathrm{B}$ cells, indeed all normal (b)
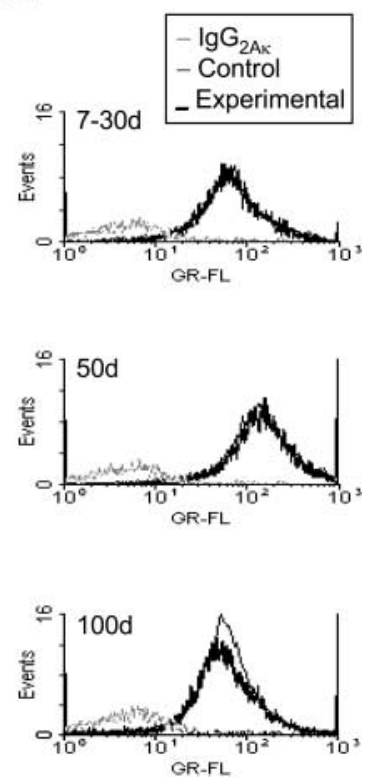

Figure 2 CD44 expression on LNC. (a) Percentage of CD44 + cells. Values are means \pm S.E.M. of four rats/group per day after first immunization. (b) Histogram overlays demonstrating the mean fluorescence intensity of CD44. E group (thicker lines), C group (thinner lines) and background staining levels assessed using irrelevant mouse immunoglobulins ( $\operatorname{lgG}_{2 A_{k}}$ ) (grey lines). The same negative background levels were observed in cells isolated from the $\mathrm{C}$ and $\mathrm{E}$ rats. $\mathrm{d}=$ days after first immunization. $\mathrm{GR}-\mathrm{FL}=$ Green Fluorescense. 
(a)

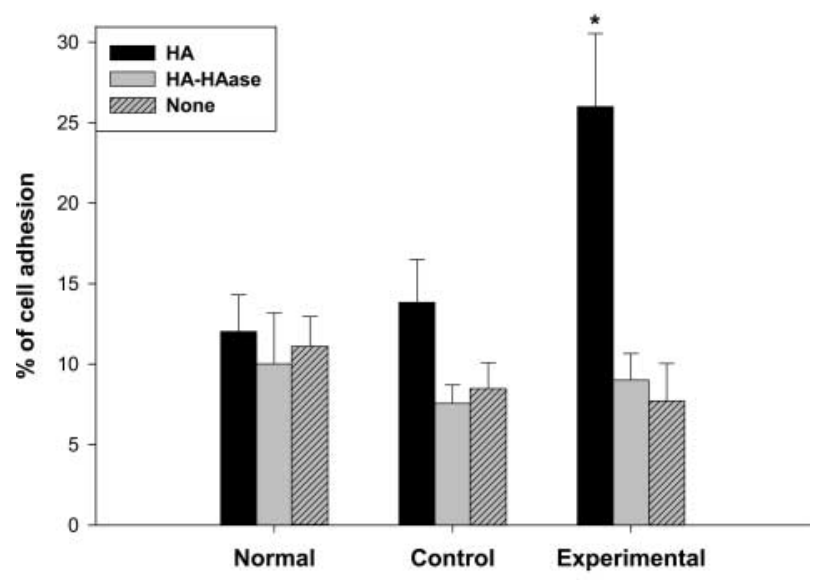

(b)

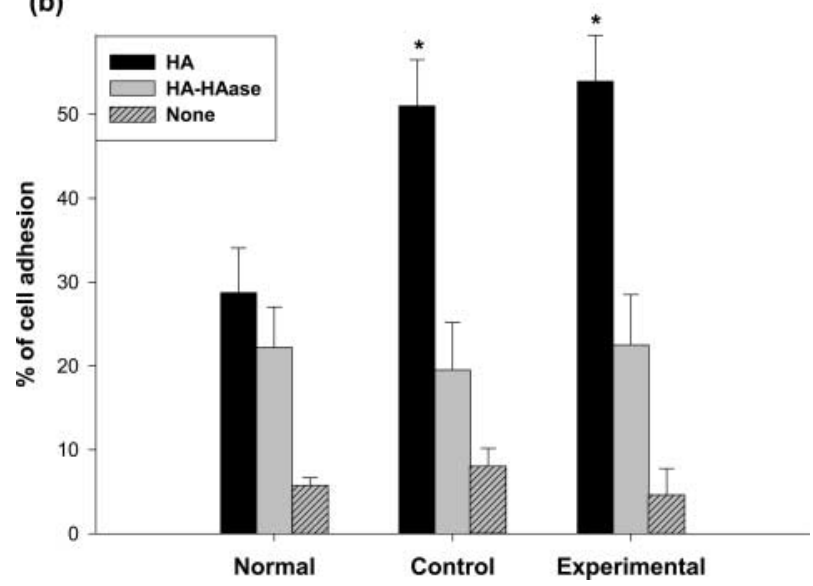

Figure 3 In vitro binding of PBMC and LNC to HA. (a) Percentage of PBMC adhesion to an HA-coated surface from $\mathrm{N}, \mathrm{C}$ and $\mathrm{E}$ rats with severe orchitis (100 days). $* P<0.05$ vs HA-HAase, vs none and vs the $\mathrm{N}$ group. (b) Percentage of LNC adhesion to HA-coated surface from $\mathrm{N}, \mathrm{C}$ and $\mathrm{E}$ rats with orchitis. $* P<0.05$ vs HA-HAase, vs none and vs the $\mathrm{N}$ group. Values are means \pm S.E.M. of four rats/group. HAHAase: HA-coated wells treated with hyaluronidase $(90 \mathrm{U} /$ well $)$ and none: uncoated wells.

hematopoietic cells that express CD44, do not appreciably bind HA in vitro (Lesley et al. 1993). An increase in mean fluorescence intensity was observed in the $\mathrm{C}$ and $\mathrm{E}$ groups after the immunization period compared with rats killed at 7-30 days, indicating higher cell membrane expression of CD44 molecules. It has been reported (Puré \& Cuff 2001) that the increased expression of CD44 is one of the mechanisms underlying the induction of the activated HA-binding form of CD44. We have demonstrated that $\mathrm{PBMC}$ and $\mathrm{LNC}$ from the $\mathrm{E}$ group were capable of specifically adhering to HA-coated plates. These results suggested the presence of cells bearing activated CD44 in rats undergoing autoimmune orchitis. The similar percentage of LNC adhesion to HA observed in the $\mathrm{C}$ and $\mathrm{E}$ groups might be due to the CFA that activates CD44 in LNC as was shown by DeGrendele et al. (1996). However, the percentage of PBMC adhesion from the $\mathrm{E}$ group was higher than the $\mathrm{C}$ group, probably dependent on the inflammatory environment that regulates the migration of these cells away from lymph nodes to peripheral blood. TNF $\alpha$ and chemokines (mainly, macrophage inflammatory protein-1 $\beta$ (MIP-1 $\beta$ ), interleukin (IL)-8 and regulated on activation, normal T cell expressed and secreted (RANTES)) present in the vicinity of blood vessel walls or present intravascularly can rapidly activate the CD44 molecule expressed on T cells (Ariel et al. 2000). These factors could be involved in the activation of CD44 in lymphomononuclear cells in EAO since we previously demonstrated an increase in $\mathrm{TNF} \alpha$ (Suescun et al. 2003) and MIP-1 $\beta$ (Guazzone et al. 2002) concentration in conditioned media from testicular macrophages of rats with severe orchitis. In addition it has been reported (Mohamadzadeh et al. 1998) that TNF $\alpha$ and IL-1 $\beta$ induce the expression of HA in endothelial cells of microvessels.

We also demonstrated a decrease in the percentage of $\mathrm{CD} 44+\mathrm{PBMC}$ and in their mean fluorescence intensity in rats with severe orchitis (100 days) compared with controls. Simultaneously, in that period a significant increase in the number of CD44 + cells was observed by immunohistochemistry in the testicular interstitium of rats with EAO compared with the $\mathrm{N}$ and $\mathrm{C}$ groups, suggesting CD44 + cell traffic from peripheral blood to the testis. The increase in the number of CD44 + cells in the testes of rats with orchitis correlated with the degree of damage.

Our results agree with the view that activated CD44 selectively participates in the enhanced homing of activated lymphocytes into the target organ and that this event may be an indicator of autoimmune activity. Estess et al. (1998) showed a close association between a small population of activated rolling $T$ cells bearing activated CD44 in the peripheral blood of patients with systemic lupus erythematosus or arthritis and active autoimmune disease. The role of CD44 in inflammation has also been shown in several experimental models such as arthritis (Zeidler et al. 1995, Halloran et al. 1996), encephalomyelitis (Brocke et al. 1999) and cutaneous inflammation (Camp et al. 1993).

In conclusion, the specific HA binding by PBMC and LNC and the increase of CD44 + cells in the testicular interstitium of rats undergoing autoimmune orchitis allow us to speculate that the CD44 molecule is involved in the recruitment of lymphomononuclear cells in the target organ and that it could play a critical role in the maintenance of autoimmune-induced inflammation.

\section{Acknowledgements}

This work was supported by grants from the Agencia Nacional de Promoción Científica y Tecnológica, the Consejo Nacional de Investigaciones Científicas y Técnicas (CONICET) and the University of Buenos Aires (UBA). V A G is a fellow of the UBA. The other authors are research 

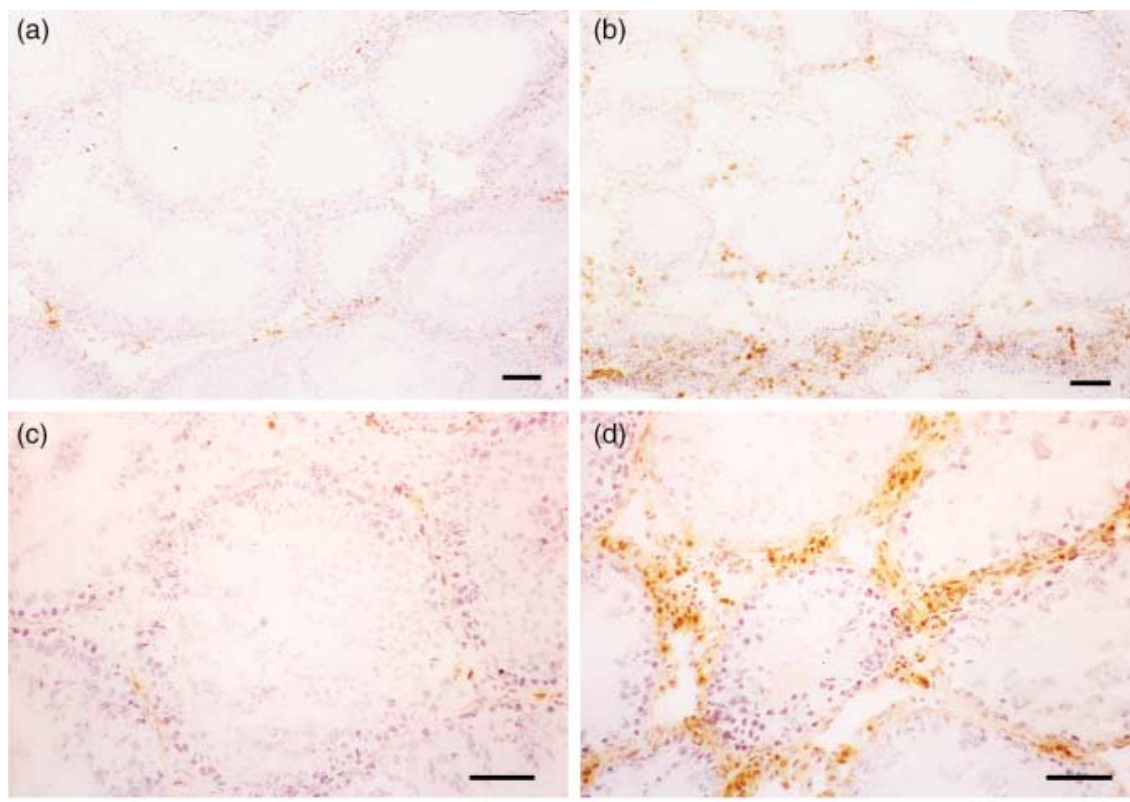

(e)

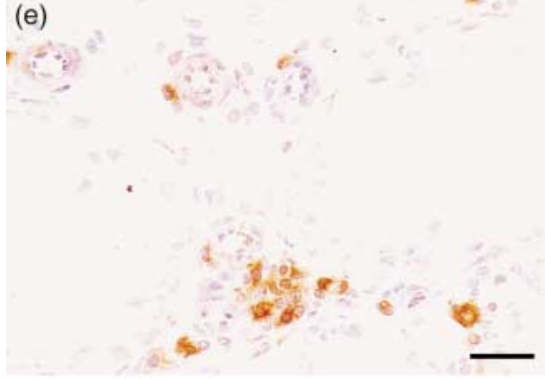

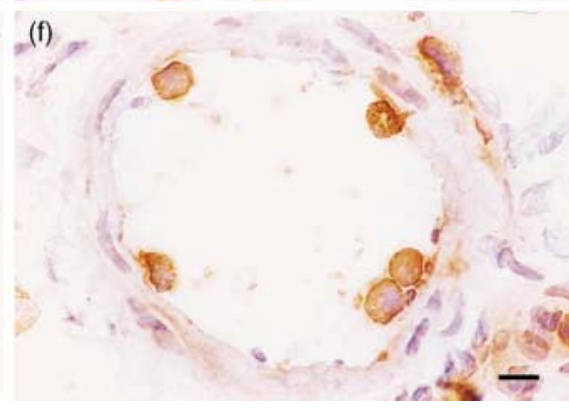

Figure 4 CD44 expression in testis sections of rats from the (a and c) C and (b, d, e and f) E group killed at 100 days. At the same magnification, the diameter of seminiferous tubules of rats from the E group was smaller than the $\mathrm{C}$ group due to the lesion of seminiferous tubules. Few CD44 + lymphomononuclear cells are seen in the interstitium of the testes of $\mathrm{C}$ rats ( $\mathrm{a}$ and $\mathrm{c}$ ) while many $\mathrm{CD} 44+$ cells are observed in $\mathrm{E}$ rats (d). CD44 + lymphomononuclear cells are present in the testicular interstitium, inside the blood vessel lumen $(\mathrm{f}$ ) or with peritubular and perivascular distribution (e). (a and b) $\times 64,(\mathrm{c}$ and d) $\times 130,(\mathrm{e}) \times 260$ and $(\mathrm{f})$ $\times 650$. Scale bars indicate $80 \mu \mathrm{m}$ for $(\mathrm{a}-\mathrm{d})$ and $40 \mu \mathrm{m}$ for (e and $\mathrm{f}$ ).

Table 1 Number $\left(\times 10^{6}\right)$ of cells (CD44 + /testis). Data were obtained by counting CD44 + cells in testis sections of three rats/group per day. Values are means \pm S.E.M.

\begin{tabular}{|c|c|c|c|c|c|}
\hline \multirow[b]{2}{*}{ Days after first immunization } & \multirow[b]{2}{*}{ Normal } & \multirow[b]{2}{*}{ Control } & \multirow[b]{2}{*}{ Experimental } & \multicolumn{2}{|c|}{ Testicular damage } \\
\hline & & & & Control & Experimental \\
\hline & $1.03 \pm 0.05$ & & & - & - \\
\hline $7-30$ & & $0.75 \pm 0.22$ & $0.94 \pm 0.08$ & - & - \\
\hline 50 & & $1.13 \pm 0.07$ & $1.43 \pm 0.11$ & - & \pm \\
\hline 100 & & $1.59 \pm 0.15$ & $3.54 \pm 0.83^{\mathrm{a}, \mathrm{b}, \mathrm{c}}$ & - & $+/++$ \\
\hline
\end{tabular}

${ }^{\mathrm{a}} P=0.013$ vs control; ${ }^{\mathrm{b}} P=0.0043$ vs normal and ${ }^{\mathrm{c}} P<0.005$ vs experimental days $7-30$ and experimental day 50.

Testicular damage is scored as, \pm+ and ++ indicating few foci, numerous foci or large areas of seminiferous tubules with germ cell sloughing respectively.

members of CONICET. We thank the Instituto Nacional de Microbiología 'A. Malbrán', División Vacunas Bacterianas, for their generous donation of Bordetella pertussis. The authors declare that there is no conflict of interest that would prejudice the impartiality of this scientific work.

\section{References}

Ariel A, Lider O, Brill A, Cahalon L, Savion N, Varon D \& Hershkoviz R 2000 Induction of interactions between CD44 and hyaluronic acid by a short exposure of human $\mathrm{T}$ cells to diverse pro-inflammatory mediators. Immunology $100345-351$.
Brocke S, Piercy C, Steinman L, Weissman IL \& Veromaa T 1999 Antibodies to CD44 and integrin alpha4, but not L-selectin, prevent central nervous system inflammation and experimental encephalomyelitis by blocking secondary leukocyte recruitment. PNAS 96 6896-6901.

Camp RL, Scheynius A, Johansson C \& Pure E 1993 CD44 is necessary for optimal contact allergic responses but is not required for normal leukocyte extravasation. Journal of Experimental Medicine 178 497-507.

DeGrendele HC, Estess P, Picker LJ \& Siegelman MH 1996 CD44 and its ligand hyaluronate mediate rolling under physiologic flow: a novel lymphocyte-endothelial cell primary adhesion pathway. Journal of Experimental Medicine 183 1119-1130. 
Doncel GF, Di Paola JA \& Lustig L 1989 Sequential study of the histopathology and cellular and humoral immune response during the development of an autoimmune orchitis in Wistar rats. American Journal of Reproductive Immunology 20 44-51.

Estess P, DeGrendele HC, Pascual V \& Siegelman MH 1998 Functional activation of lymphocyte CD44 in peripheral blood is a marker of autoimmune disease activity. Journal of Clinical Investigation 102 1173-1182.

Floderus S 1944 Untersuchungen uber den Bau der menschlichen Hypophyse mit besonderer Berucksihtigung der quantitativen mikromorphologischen Verhaltnisse. Acta Pathologica Microbiologica Scandinavica 53 (Suppl) 1-276.

Gee K, Kozlowski M \& Kumar A 2003 Tumor necrosis factor-alpha induces functionally active hyaluronan-adhesive CD44 by activating sialidase through p38 mitogen-activated protein kinase in lipopolysaccharide-stimulated human monocytic cells. Journal of Biological Chemistry 278 37275-37287.

Gee K, Kryworuchko M \& Kumar A 2004 Recent advances in the regulation of CD44 expression and its role in inflammation and autoimmune diseases. Archivum Immunologiae et Therapiae Experimentalis 52 13-26.

Guazzone V, Rival C, Denduchis B \& Lustig L 2002 Expresión de la proteína inflamatoria de macrófagos-1 $\beta$ (MIP-1 $\beta$ ) en un modelo de orquitis autoinmune experimental. Medicina 62416 (Abstract).

Guazzone VA, Rival C, Denduchis B \& Lustig L 2003 Monocyte chemoattractant protein-1 (MCP-1/CCL2) in experimental autoimmune orchitis. Journal of Reproductive Immunology 60 143-157.

Hales DB, Diemer T \& Hales KH 1999 Role of cytokines in testicular function. Endocrine 10 201-217.

Halloran MM, Szekanecz Z, Barquin N, Haines GK \& Koch AE 1996 Cellular adhesion molecules in rat adjuvant arthritis. Arthritis and Rheumatism 39 810-819.

Itoh M, Hiramine C, Mukasa A, Tokunaga Y, Fukui Y, Takeuchi Y \& Hojo K 1992 Establishment of an experimental model of autoimmune epididymo-orchitis induced by the transfer of a T-cell line in mice. International Journal of Andrology 15 170-181.

Lesley J, Hyman R \& Kincade PW 1993 CD44 and its interaction with extracellular matrix. Advanced Immunology 54 271-335.

Levesque MC \& Haynes BF 1996 In vitro culture of human peripheral blood monocytes induces hyaluronan binding and up-regulates monocyte variant CD44 isoform expression. Journal of Immunology 156 1557-1565.
Levesque MC \& Haynes BF 1997 Cytokine induction of the ability of human monocyte CD44 to bind hyaluronan is mediated primarily by TNF-alpha and is inhibited by IL-4 and IL-13. Journal of Immunology 159 6184-6194.

Lustig L, Lourtau L, Perez R \& Doncel GF 1993 Phenotypic characterization of lymphocytic cell infiltrates into the testes of rats undergoing autoimmune orchitis. International Journal of Andrology 16 279-284.

Mohamadzadeh M, DeGrendele H, Arizpe H, Estess P \& Siegelman M 1998 Proinflammatory stimuli regulate endothelial hyaluronan expression and CD44/HA-dependent primary adhesion. Journal of Clinical Investigation 101 97-108.

Nandi A, Estess P \& Siegelman M 2004 Bimolecular complex between rolling and firm adhesion receptors required for cell arrest; CD44 association with VLA-4 in T cell extravasation. Immunity 20 455-465.

Puré E \& Cuff CA 2001 A crucial role for CD44 in inflammation. Trends in Molecular Medicine 7 213-221.

Suescun MO, Rival C, Theas MS, Calandra RS \& Lustig L 2003 Involvement of tumor necrosis factor-alpha in the pathogenesis of autoimmune orchitis in rats. Biology of Reproduction $\mathbf{6 8}$ $2114-2121$.

Theas S, Rival C \& Lustig L 2003 Germ cell apoptosis in autoimmune orchitis: involvement of the Fas-FasL system. American Journal of Reproductive Immunology 50 166-176.

Tung KSK, Taguchi O \& Teuscher C 1994 Testicular and ovarian autoimmune diseases. In Guidebook to Animal Models for Autoimmune Diseases, pp 267-290. Eds IR Cohen \& A Millers. New York: Academic Press.

Zeidler A, Brauer R, Thoss K, Bahnsen J, Heinrichs V, JablonskiWestrich D, Wroblewski M, Rebstock S \& Hamann A 1995 Therapeutic effects of antibodies against adhesion molecules in murine collagen type II-induced arthritis. Autoimmunity 21 245-252.

Received 24 May 2004

First decision 28 July 2004

Revised manuscript received 17 November 2004

Accepted 15 February 2005 